\title{
Variation in student success across Europe: Exploring the relevance of system-level explanations
}

\begin{abstract}
Student success is often defined as students completing their degree, preferably within the estimated time to degree. However, if we apply this definition, student success is quite varied if we compare countries in Europe (OECD Education at a Glance 2013, Vossensteyn et al 2015). The article identifies and discusses some system-level factors that is often mentioned as possible explanations of these differences including costs, selection and admission system differences and the structuring of higher education offerings, and the relationship between higher education and the labour market. However, based on existing data, the identified system-level factors do not correlate with the empirical variation in student success, and the article ends with some reflections about future research needs to advance the knowledge about student success.
\end{abstract}

Key words: student success, higher education, completion, drop-out, Europe 


\section{Introduction}

As higher education has become a mass phenomenon globally, there is increased public attention to how the higher education sector is performing on dimensions such as quality, relevance and efficiency (Yorke \& Longden 2004). Given the huge amount of economic and human resources going into the sector, public authorities in a number of countries are interested in investigating the returns of higher education, either with regards to graduation on time, and that students starting higher education are not dropping out, or with regards to the employability of graduates from universities and colleges and whether the competence and skills acquired are relevant in a rapidly shifting labour market (Vossensteyn et al 2015). As such, student success is a label that relates not only to the individual accomplishments of the graduate, but also to the dimensions of higher education as a public good, in terms of generating quality, relevance and efficiency for the society at large.

The fact that there are several ways of understanding student success, suggest that the term cannot be considered an established concept in higher education. One line of research, which has been very prominent in the US, is to define success in very broad terms, not just as completion of a course or a degree suggesting that success in higher education is also linked to creating good citizens or good learners (see for example Astin 1975, 1993, Pascarella \& Terenzini 1991, 2005, Kuh et al 2006). Alongside this line of research there is also a large amount of research in the US focusing on various ways of measuring student completion and using various independent variables, primarily focused on prior educational achievements, to predict the likelihood of success (for examples see Shulruf, Hattie \& Tumen 2008, Jones-White et al 2010). The approach to measuring student success in Europe has been more varied, with focus on completion of course and/or degree as well as successful outcomes in the labour market.

Acknowledging that student success is a label that covers many different dimensions, the current article still employs a more limited perspective and focuses mostly on the economic aspects of the term i.e., whether students are completing their degree, and preferably within the estimated time to degree. OECD statistics (2013) show that time to degree and drop-out rates are varying considerably between countries, and that there are many potential factors impacting the outcome on this issue (Vossensteyn et al. 2015). The fact that higher education is a sector that in most countries is strongly affected by national, cultural and socio-economic traditions and characteristics (Clark 1983), may explain this variation in efficiency. For example, in Europe, graduation rates vary quite a lot between what seems to be high-performing countries such as Denmark, Finland, and the UK, and what seems to be relatively low-performing countries such as Norway, Sweden and Hungary (OECD 2013, Quinn 2013 , Vossensteyn et al 2015). However, these countries are also very different with respect to the design and organization of their higher education systems, and as such, Europe makes up an interesting laboratory for studying the potential impact of system-level factors affecting graduation and drop-out. Hence, the aim of the current article is to look into the relevance of some of the key system-level factors often believed to have an impact on student performance with respect to completion and drop-out, discuss their significance, and reflect on possible research implications related to how the research in this area may be advanced in the future.

The remains of the article are organized as follows: Based on existing literature on completion and drop-out, three factors which are thought of as having impact on the level of completion and dropout rates are identified. The three factors are: i) the implications of the cost level of higher education for the individual student, ii) the consequences different systems of access and/or selection practices may have for level of completion and drop-out rates, as well as iii) the influence of the labour market situation and conditions in a country. Based on these factors, empirical illustrations are provided from various European countries, and the significance of the factors and their interrelationship is discussed. We close the article by providing possible avenues for further research in the area of student success. 


\section{Key factors affecting completion and dropout rates}

Research on student success in terms of completion (and drop-out) has a long history in higher education (Astin 1993, Kuh et al. 2006, Aljohani 2016). In general, it is acknowledged that student success is a very complex phenomenon although a number of studies tend to agree that valid explanations are found with respect to i) individual characteristics of students and their background (e.g., gender, motivation, and the educational and socio-economic background of their parents) (see e.g., Shulruf et al. 2008, Chen 2012, Severiens \& Dam 2012, Quinn 2013, Bradley 2017), and ii) characteristics of the higher education institution and how the institution may integrate students in an academic and social learning environment (see e.g., Astin 1993, Pascarella \& Terenzini 1999, 2005, Kuh et al. 2006). While acknowledging this research, the current article employs a different point of departure. As student success seems to differ considerable between countries, it is also reasonable to assume that there might be system-level characteristics that may impact on student success, not least as a consequence of policy choices made in individual countries. Hence, in this article, a public policy perspective is applied where completion is seen as an issue which can be addressed through the key tools of government, especially funding, organization and information measures (Hood \& Margetts 2007).

In most countries funding of higher education is one of the most important issue for public policy, especially concerning what the private cost of education should be. In higher education systems with tuition fees is the private cost of not completing or finishing delayed higher than in higher education systems without tuition fees. Altbach, Reisberg and Rumbley (2009:xii) point out that while higher education traditionally has been seen as a public good, which contributes to society by improving human capital and boosting economic development, it is now gradually more being "seen as a private good, largely benefiting individuals". This has implications for how higher education is funded, not least since mass higher education has created funding shortages, and where also public higher education institutions have to start generating some of their own revenue. This is by some researchers seen as a major concern. "The growing emphasis on cost recovery, higher tuition and university-industry links distracts from the traditional social role and service function of higher education that are central to contemporary society" (Altbach et al 2009:xii). Hence, the change in how higher education is viewed has implications for higher education systems, and may in some cases have given way to rising tuition fees (England is perhaps the prime example here). Still, the indirect implication of this for student success is that high tuition fees provide a strong incentive for students to complete, and possibly also on time.

Another key area for public policy is to decide upon the access practices within different higher education systems, i.e. how easy or difficult it is for students to enter into the sector. It is possible to distinguish access systems in a range of ways. According to Trow $(1973,2006)$, will the move from elite to mass higher education have a range of implications for higher education, and among them are changes in access and admission. In general, an increase of participants in the system affects the ways access and admission is designed. Admission can be configured by concentrating on how students are channelled into or out of higher education via upper secondary education (by attending a type of upper secondary education which makes them eligible to enter higher education) or by concentrating on when selection takes place - if selection is done before the student enter higher education, usually based on grades from upper secondary, or if it is done through achievement after entering higher education. Orr et al (2017) focus on the first approach in their overview of European admissions systems, a project done for the European commission. They choose to focus on how secondary education in some countries stream students into higher education (while students choosing a different path are streamed away from higher education) combined with the selectivity of institutions (how higher education institutions choose students), and see this together as a process. The alternative way of viewing this is focusing on when selection takes place, or what kind of selection is it. Selection can either take place before the student start higher education, preselection, or after the student already has started a programme, commonly at the end of the first 
course or the first year of studying, denoted as post-selection. Poland and Austria are examples of countries which practices this type of selection of students. In countries with post-selection processes the great majority of programmes are open access, all students who are eligible for higher education entry can start a programme. Selection is done through the exam after the first semester or first year which creates a sort of "survival of the fittest" approach to selection in higher education. Hence, the way the access system is designed may in some ways be linked to how the expansion of the higher education system has been handled, which has been pointed out for example for Italy by de Francesco (1978) and by Tuijnman (1990) for Sweden. As a general rule, one might also expect that liberal access policies would have negative consequences for student success as more poorly qualified and less motivated students would more likely drop-out from their studies.

A third factor which might have implications for the completion rate in a country is the labour market situation, as students probably are more eager to complete their degree in countries where there are more jobs for higher education graduates, and that students in countries with poor labour market would prioritise having a higher education degree. While public policy may have less direct impact on the functioning of the labour market, there have been arguments made that governments (Germany, Italy and Norway are examples) have used higher education as a form of "parking lot", where young people are being given an alternative to unemployment and where students continue to be enrolled in higher education despite other preferences (Oppedisano 2007, Bratti, Checchi \& de Blasio 2008). Public policy options here might be to promote higher education qualifications and continuing education in times when the labour market prospects are poor. Studies done in a period when the business cycle and the labour market prospects in Norway were particularly good indicate that this might have positive implications, both for labour market adjustment and for risk of unemployment or having irrelevant work (doing a job that does not require that level of education) among graduates (Støren \& Arnesen 2007, Støren, Wiers-Jenssen \& Arnesen 2011). Hence, based on this we would expect that drop-out rates would be rather high when the labour market is in need of people, and that completion rates would be high when the labour market is poor.

\section{Data, methods and limitations}

There are generally few examples of cross-country comparisons of dropout rates. This may be related to the fact that a "significant number of countries do not systematically calculate completion and/or drop-out rates" (EC/EACEA/Eurydice 2014:10). Hence, all studies intending to compare dropout rates across countries face the same problem: data on dropout and completion is rarely available. On top of that comes the problem that dropout and completion is being defined and measured somewhat differently in different countries, which contributes to making comparisons very difficult. Currently, the only regularly publishing of data for several countries on the issue of completion is the OECD, in Education at a Glance. Since 1998, OECD has published what they first labelled as "higher education survival rates" (OECD 1998:189) and later have been called "graduation rates" and "rates for those leaving without a tertiary qualification" (OECD 2008: Table A4.1; 2010: Table A4.1). However, there are a range of challenges linked to using these data. The critique against the OECD data include the fact that two different methods are used to calculate completion rate, and secondly that this rate is not reported on by all countries. Other obstacles are related to the time frame of the measure, and different challenges that this may pose to the data, in addition to the crudeness of the measure, as it is insensitive to differences in access policies to higher education and the logic of the higher education system in different countries. As such, there are methodological and empirical limitations concerning the data made available by the OECD. 
Still, since OECD holds the only available data gathering on completion rates in higher education in Europe, we will use this data (see table $1^{1}$ ) as the best ones available to explore whether and how system-level factors may contribute to research in this area. The data also give an indication of how student success has been developing in the recent years in some European countries. However, since we only have data for two points in time, we cannot really say anything about trends; only observe if there are changes from first to second data collection. The OECD does not collect data on completion rates on a yearly basis, and have not published data in this format after 2013. However, as the purpose of the current article is to explore analytical explanations for drop-out and completion rates, where recent trends with respect to such issues are of less relevance, we do not perceive it as a major problem using older data.

In the table below, completion rates are provided for a selection of European countries for ISCED 5A which equals theoretical tertiary education at undergraduate level.

\section{INSERT TABLE 1 HERE}

Table 1 indicate that completion rates in European higher education at undergraduate level differ quite a lot, both in 2005 and in 2011. Only three countries, Finland, Netherlands and Slovak Republic have experienced an increase from 2005 to 2011, some countries are characterised by much stability (e.g., Denmark and the UK), while yet others have seen a decrease in completion rates. For our purposes, this table is the starting point for dividing the countries into three simple categories: Those that can be said to have a high level of completion (above 75 percent); those that have low completion rate (59 percent and below), and those countries scoring average on completion rates (between 60-74 percent). This categorization then produces three sets of countries using the 2011 completion rates as point of departure:

- Low scoring countries on completion: Hungary, Norway and Sweden

- Average scoring countries on completion: Austria, Belgium, France, the Netherlands, Poland, Slovak Republic and Portugal

- High scoring countries on completion: Czech Republic, Denmark, Finland, Turkey and the UK

While we acknowledge that the categorization of countries into low, average and high on completion indeed can be questioned, the purpose here is only to explore whether the variation in completion rate between countries can be considered as a promising route forward for future research on system-level impact on student success.

\section{Empirical indications of higher education cost, access policies and labour market challenges}

As suggested earlier may the private cost of participating in higher education have implications for completion and drop-out rates. It has at least been argued that tuition fees may have an impact on completion rates as it makes it non-completion more expensive for the student. The cost of their educational investment is not just foregone income while studying, but also a payment up-front to take part in the educational offering. Table 2 show an overview of European countries which are tuition free, which have tuition and the level of this tuition. As illustrated in the table, half of the countries on the list do not charge tuition fees, and among the eight countries which charge tuition, three have low tuition fees and only one, the UK have high tuition fees. However, the UK is also one of the countries which have high completion rates, suggesting a correlation. On the other hand, Denmark also has comparably high completion rates, and no tuition fees, indicating no correlation.

\section{INSERT TABLE 2 HERE}

\footnotetext{
${ }^{1}$ Data is extracted from two versions of Table A4.1 in Education at a Glance (2008; 2013). The data in these tables stem from two different data collections: in 2005 for the 2008-publication and in 2011 for the 2013publication. These are the two latest data collections on this indicator.
} 
Another factor identified which could be imagined having significance for completion is how the system of access to higher education is structured. As mentioned earlier there are several ways of viewing the issue of access and selection. Orr et al (2017) recently presented a structured overview of European access systems in a report to the European Commission (see table 3). Table 3 displays a distinction which divides systems into four different types, and these types have different features, scoring on either effectiveness, efficiency or equality. If we compare the grouping of countries in table 3 with our categorizations of low, average and high achievers on completion, a very mixed picture emerges, where no admission systems seem to have a strong correlation with respect to completion.

\section{INSERT TABLE 3 HERE}

As indicated earlier may access policies have a direct impact on student success, and one way to investigate this issue is to look at the correlation between enrolment rate and completion rate. Based on the argument that widening access to higher education would give a more heterogeneous student body, particularly with varying preparedness for higher education, we could assume that countries with the highest rates of enrolment among 20-29-yearolds also would have the lowest rates of completion. However, as figure 1 indicates there is no distinct pattern in the data supporting this assumption. Among countries with high completion rates, Denmark has among the highest enrolment rates while France and the UK have relatively low enrolment rates. Similarly, among countries with low completion rates we find Hungary which have a low enrolment rate and Sweden which have a relatively high enrolment rate. Thus, the correlation between enrolment rate and completion rate is low which contradicts the argument that widening access to higher education necessarily drives lower completion rates.

\section{INSERT FIGURE 1 HERE}

The final factor identified as potentially important in the current paper is the labour market situation for people holding tertiary qualifications. While this situation may change somewhat over time, not least due to upswing in the economy worldwide, in many countries the labour market situation is quite stable for those holding these qualifications where some countries may offer many job opportunities for higher education graduates, while others may offer few. For example, during the late 1990s it was argued that students in Italy would stay in higher education, instead of completing and risking the chance of ending up as unemployed. Hence, students may continue being registered as a student while they actually are searching for a job (the "parking-lot" scenario) (Oppedisano 2007, Bratti, Checchi \& de Blasio 2008). But this may also take the opposite turn, that students are more eager to complete and get a job when labour market opportunities are bright (Støren \& Arnesen 2007, St $\varnothing$ ren, Wiers-Jenssen \& Arnesen 2011). In this setting the sheepskin effect of education, the value of holding a diploma, is also a relevant argument (Hungerford \& Solon 1987, Jaeger \& Page 1996). Using the latest available statistics from the OECD on unemployment rates among those holding higher education qualifications show huge variation between countries.

\section{INSERT FIGURE 2 HERE}

As figure 2 indicate, most of the countries for which we have completion rates on have also quite low unemployment rate for people with higher education qualifications. The rates range from under 2 per cent for Norway, to 5,5 per cent for France and 6 per cent for the Slovak Republic. Turkey, and in particular Portugal have relatively high unemployment rate among the population holding a tertiary degree. If we compare unemployment rates with our categorizations, we find again few correlations. The UK, which is a high-performing country on completion do have a low unemployment rate, but countries scoring low on completion - for example Hungary and Norway - also score low on 
unemployment. This indicates that the employment situation in a country might not necessary contribute to explaining the rate of completion in higher education, and the assumption that governments use higher education as a parking lot to avoid high unemployment among the youth might thus not hold.

\section{Discussion and research implications}

The aim of the current paper has been to explore how some system-level characteristics correlate with high or low completion rates. Although the quality of the data on completion rates collected by the OECD could have been better due to a lack of methodological consistency in how completion is defined in different countries, our paper suggest an intriguing paradox regarding country differences and completion rates: While some countries consistently score high (and low) on completion, suggesting that there might be some significant country (system) characteristics associated with (non) completion, the same countries display a quite mixed picture regarding costs, admissions and labour market characteristics. To provide some examples; while the UK score high on completion, and is a country with high tuition fees, a double selection admission system, and lower graduate unemployment than OECD average, Denmark is also scoring high on completion, have no tuition fees, a school selection admission system, and higher graduate unemployment than OECD average. Among the countries scoring low on completion rates, Norway has no tuition fees while Hungary have quite high fees in some study programs. These two countries have different admission systems, and but quite low graduate unemployment rate.

There are several possible explanations for why we have trouble identifying strong correlations between system-level characteristics and completion. The first explanation underscores much of the existing research on completion and drop-out, and points to the complexity associated with this phenomenon. This may relate to how system-level characteristics are interrelated to individual and institutional characteristics, and points to research that take into account the many social, academic, and organizational factors and the need for more sophisticated modelling of potential causal relationships among them (Yorke \& Longden 2008; Jones et al. 2010, Schnepf 2017), and research that aims at solving the many methodological challenges in this area, not least concerning how more reliable and consistent data can be developed (Thomas \& Hovdhaugen 2014).

The second explanation is related to the possibility that public policy may have less impact on completion and drop-out than believed, and that there might be other system-level factors that may have more significance than those identified in the current paper. Such factors might include salary differences between those with higher education and those without, or lack of such differences in the labour market (see also Støren \& Arnesen 2007). Troelsen \& Laursen (2014) have also suggested that there might be more inherent cultural differences between different countries affecting completion. They suggest that such national cultures may relate to how higher education is reflecting key characteristics of the national culture (e.g., individualism, collectivism, power distances etc.), but also how national cultures are reflected in the teaching and learning traditions in a country. This may open up for more in-depth research where studies of completion should go more in-depth, and perhaps be more closely linked to studies of pedagogical design and how learning environments are shaped.

The third explanation, related to the one above, is that completion rates also have to be understood in relation to the political ideology of specific countries, and that we need to acknowledge that in some countries the higher education system is linked to overarching ideas about democracy, participation and equality, and how such ideas are translated into practice (Thomas \& Hovdhaugen 2014). For example, in several German-speaking countries higher education have been open to all qualified applicants, where the idea of access has been more important than the goal of completion. Clark (1983) also pointed out several decades ago that distinct differences can be found between 
European higher education systems, where some allow for more influence of market mechanisms while others are more inclined to tighter state steering. In this perspective, completion rates are embedded in a much wider context where issues of skills formation trajectories and macro-level societal development are the key issues (Busemayer \& Iversen 2014).

To conclude, while much prior research on student completion have focused on micro-level and organizational level factors which may impact completion, the key message in the current article is that we need to achieve a better understanding of why there are so distinct and consistent differences in completion rates at country/system level. While our research hints at rather moderate, or at least very complex, impact of public policies, we do hope we have indicated some future research paths into this area which could advance the research on this important topic. 


\section{References:}

Altbach, P. G., L. Reisberg \& L. Rumbley (2009): Trends in Global Higher Education: Tracking an Academic Revolution. A Report Prepared for the UNESCO 2009 World Conference on Higher Education. Paris: UNESCO

Aljohani, O. (2016): A review of the contemporary international literature on student retention in higher education. International Journal of Education and Literary Studies 4(1).

Astin, A. W. (1975): Preventing Students from Dropping out. San Francisco: Jossey-Bass

Astin, A. W. (1993): What matters in college? Four critical years revisited. San Francisco: Jossey-Bass Bowes, L., L. Thomas, L. Peck \& L. Natwani, T. (2013): International research on the effectiveness of widening participation. Bristol: HEFCE and OFFA.

Bradley, H. (2017): 'Should I stay or should I go'?: dilemmas and decisions among UK undergraduates. European Educational Research Journal, 16(1), 30-44.

Bratti, M., D. Checchi \& G. de Blasio (2008): Does the Expansion of Higher Education Increase the Equality of Educational Opportunities? Evidence from Italy. Labour: review of labour economics and industrial relations, 22(1): 53-88

Busemayer, M. \& Iversen, T. (2014) The political economy of skills and inequality. Socio-Economic Review, 12(2), 241-243.

Clark, B. R (1983): The Higher Education System: Academic Organization in Cross-national Perspective. Berkeley: University of California Press

Chen, R. (2012): Institutional characteristics and college student drop-out risks: A multilevel event history analysis. Research in Higher Education, 53(4) 487 - 505.

De Francesco, C. (1978): The growth and crisis of Italian higher education during the 1960s and 1970s. Higher Education, 7(2): 193-212

European Commission/EACEA/Eurydice (2014): Modernisation of Higher Education in Europe: Access, Retention and Employability 2014. Eurydice Report. Luxembourg: Publications Office of the European Union.

Hood, C. \& H. Z. Margetts (2007): The tools of government in the digital age. New York: Palgrave MacMillan.

Hungerford, T \& G. Solon (1987): Sheepskin Effects in the Returns to Education. The Review of Economics and Statistics, 69 (1): 175-177

Jones-White, D., P.M. Radcliffe, R.L. Huesman Jr, J.P. Kellogg (2010): Redefining Student Success: Applying Different Multinomial Regression Techniques for the Study of Student Graduation Across Institution of Higher Education. Research in Higher Education, 51(2): 154-174

Jaeger, D. A. \& M. E. Page (1996): Degrees Matter: New Evidence on Sheepskin Effects in the Returns to Education. The Review of Economics and Statistics, 78 (4): 733-740

Kuh, G. D., J. Kinzie, J. A Buckley, B. K: Bridges, J.C. Hayek (2006): What Matters to Student Success: $A$ Review of the Literature. Commissioned Report for the National Symposium on Postsecondary Student Success: Spearheading a Dialog on Student Success. Washington, D.C: NCES. Available online: https://nces.ed.gov/npec/pdf/kuh team report.pdf

OECD (1998): Education at a Glance 1998. Paris: OECD.

OECD (2008): Education at a Glance 2008. Paris: OECD.

OECD (2013): Education at a Glance 2013. Paris: OECD.

OECD (2016): Education at a Glance 2016. Paris: OECD.

Oppedisano, V. (2007): Higher education in Italy: parking lot or human capital investment? University of Turin Working paper published online: http://www.aiel.it/page/old paper/oppedisano.pdf

Orr. D., A. Usher, C. Haj, G. Atherton, I. Geanta (2017): Study on the impact of admission systems on higher education outcomes. Final report. Brussels: European Commission

Pascarella, E. T. \& P. T. Terenzini (1991): How college affects students. Findings and insights from twenty years of research. San Francisco: Jossey-Bass.

Pascarella, E. T. \& P. T. Terenzini (2005): How college affects students. A third decade of research. San Francisco: Jossey-Bass. 
Quinn, J. (2013): Drop-out and Completion in Higher Education in Europe among Students from Under-represented Groups. NESET-report, October 2013. Brussels: European Commission.

Schnepf, S. V. (2017): How do Tertiary Dropouts Fare in the Labour Market? A Comparison between EU Countries, Higher Education Quarterly, 71(1): 75-96

Severiens, S. \& G. Dam (2012): Leaving college: A gender comparison in male and female dominated programs. Research in Higher Education, 53(4) $453-470$.

Shulruf, B. J. Hattie \& S. Tumen (2008): Individual and school factors affecting students' participation and success in higher education, Higher Education, 56(5): 613-632

Støren L. A \& C. Å. Arnesen (2007): Winners and Losers. In J. Allen \& R. van der Velden (red.) The Flexible Professional in the Knowledge Society: General Results from the REFLEX project. Report to the EU Commission. Maastricht: Research Centre for Education and the Labour Market, Maastricht University.

Støren L. A, J. Wiers-Jenssen \& C. Å. Arnesen (2011): Employability and Mobility of Norwegian Graduates Post Bologna. In H. Schomburg \& U. Teichler (Eds.) Employability and Mobility of Bachelor Graduates in Europe. Rotterdam: Sense Publishers

Thomas, L. \& Hovdhaugen, E. (2014): Complexities and Challenges of Researching Student Completion and Non-completion of HE Programmes in Europe: a comparative analysis between England and Norway. European Journal of Education, 49 (4): 457-470

Tinto, V. (1993): Leaving College: rethinking the causes and cures of student attrition (2nd ed.) Chicago, University of Chicago Press.

Troelsen, R. \& P.F. Laursen (2014): Is drop-out from university dependent on national culture and policy? The case of Denmark. European Journal of Education, 49(4), 484-496.

Trow, M. (1973) Problems in the transition from elite to mass higher education. Report for Carnegie Commission on Higher Education. (Berkeley, CA: Carnegie Commission on Higher Education).

Trow, M. (2006) Reflextions on the transition from elite to mass to universal access: Forms and phases of higher edcuation in modern societies since WWII, in: J. J. F. Forest \& P. G. Altbach (Eds) International handbook of higher education. vol. 1 (Dordrecht: Springer), 243-280.

Tuijnman, A. (1990): Dilemmas of open admissions policy: quality and efficiency in Swedish higher education. Higher Education, 20(4): 443-457

Vossensteyn, H., B. Stensaker, A. Kottmann, E. Hovdhaugen, B. Jongbloed, S. Wollscheid, F. Kaiser, L. Cremonini (2015): Dropout and Completion in Higher Education in Europe. Main report. Brussels: European Commission

Yorke, M., \& B. Longden (Eds.)(2004): Retention and Student Success in Higher Education. Maidenhead: Society for Research into Higher Education/Open University Press.

Yorke, M., \& B. Longden (2008): The first-year experience of higher education in the UK. Final report. York: The Higher Education Academy. 
Table 1: OECD data on completion rates, ISCED 5A

\begin{tabular}{|c|c|c|c|c|c|c|c|}
\hline & \multicolumn{3}{|c|}{ Education at a Glance 2008} & \multicolumn{3}{|c|}{ Education at a Glance 2013} & \multirow{2}{*}{$\begin{array}{c}\text { Change } \\
\text { (cases where there } \\
\text { is change in } \\
\text { numbers and } \\
\text { method are marked } \\
\text { by parenthesis) }\end{array}$} \\
\hline & Method & $\begin{array}{l}\text { Year for } \\
\text { new } \\
\text { entrants }\end{array}$ & $\begin{array}{l}\text { Completion } \\
\text { rate } 2005\end{array}$ & Method & $\begin{array}{l}\text { Year for } \\
\text { new } \\
\text { entrants }\end{array}$ & $\begin{array}{c}\text { Completion } \\
\text { rate } 2011\end{array}$ & \\
\hline Austria & Cross-section & $2000-03$ & 71 & Cross-section & $2006-08$ & 65 & Decrease \\
\hline Belgium (FI.) & Cross-section & $\begin{array}{l}1998- \\
2001\end{array}$ & 76 & True cohort & 2007-08 & 69 & (Decrease) \\
\hline $\begin{array}{l}\text { Czech } \\
\text { Republic }\end{array}$ & Cross-section & $\mathrm{m}$ & 68 & True cohort & 2001 & 75 & (Increase) \\
\hline Denmark & True cohort & $1995-96$ & 81 & True cohort & $2000-01$ & 80 & Decrease \\
\hline Estonia & Cross-section & 2003 & 63 & $\mathrm{~m}$ & $\mathrm{~m}$ & $\mathrm{~m}$ & $\mathrm{~m}$ \\
\hline Finland & True cohort & 1995 & 72 & True cohort & 2000 & 76 & Increase \\
\hline France & True cohort & $\begin{array}{l}1996- \\
2003\end{array}$ & 64 & $\begin{array}{c}\text { Longitudinal } \\
\text { survey }\end{array}$ & 2002-09 & 68 & (Increase) \\
\hline Germany & Cross-section & 2001-02 & 77 & True cohort & $\begin{array}{l}1999- \\
2002 \\
\end{array}$ & $\mathrm{~m}$ & $\mathrm{~m}$ \\
\hline Hungary & Cross-section & 2001-04 & 57 & Cross-section & $\begin{array}{c}2006-07 / \\
2009-10 \\
\end{array}$ & 48 & Decrease \\
\hline Iceland & True cohort & $1996-97$ & 66 & $\mathrm{~m}$ & $\mathrm{~m}$ & $\mathrm{~m}$ & $\mathrm{~m}$ \\
\hline Italy & True cohort & 1998-99 & 45 & $\mathrm{~m}$ & $\mathrm{~m}$ & $\mathrm{~m}$ & $\mathrm{~m}$ \\
\hline Netherlands & True cohort & $1997-98$ & 71 & True cohort & 2003-04 & 72 & Increase \\
\hline Norway & True cohort & 1994-95 & 67 & True cohort & $\begin{array}{c}1999- \\
2000 \\
\end{array}$ & 59 & Decrease \\
\hline Poland & Cross-section & 2001-04 & 63 & Cross-section & 2006-09 & 62 & Decrease \\
\hline Portugal & Cross-section & 2001-06 & 69 & Cross-section & $2006-10$ & 67 & Decrease \\
\hline $\begin{array}{l}\text { Slovak } \\
\text { Republic }\end{array}$ & Cross-section & 2000-03 & 70 & Cross-section & 2006-09 & 71 & Increase \\
\hline Spain & $\mathrm{m}$ & $\mathrm{m}$ & $\mathrm{m}$ & Cross-section & 2008-09 & $\mathrm{m}$ & $\mathrm{m}$ \\
\hline Sweden & True cohort & $1995-96$ & 69 & True cohort & $2002-03$ & 48 & Decrease \\
\hline Switzerland & True cohort & $\begin{array}{l}1996- \\
2001 \\
\end{array}$ & 70 & $\mathrm{~m}$ & $\mathrm{~m}$ & $\mathrm{~m}$ & $\mathrm{~m}$ \\
\hline Turkey & $\mathrm{m}$ & $\mathrm{m}$ & $\mathrm{m}$ & Cross-section & 2007-08 & 75 & $\mathrm{~m}$ \\
\hline $\begin{array}{l}\text { United } \\
\text { Kingdom }\end{array}$ & Cross-section & 2003-04 & 79 & Cross-section & 2007-08 & 79 & No change \\
\hline
\end{tabular}

Source: OECD, Education at a Glance 2008, Education at a Glance 2013, Indicator A4.1, amendments by CHEPS/NIFU, $\mathrm{m}=$ missing data. A variant of this table is also published as table 4.1 in Vossensteyn et al (2015:31).

European countries which have missing data at both points in time are kept out of the table, and includes Bulgaria, Croatia, Cyprus, Greece, Ireland, Latvia, Lithuania, Luxembourg, Macedonia, Malta, Montenegro, Romania, Serbia, Slovenia. 
Table 2: Overview of tuitions fees at public institutions in some European countries

\begin{tabular}{|c|c|c|}
\hline Country & Tuition for EU-citizens & Level of tuition at public institutions \\
\hline Austria & No* & \\
\hline Belgium & Yes* & Low: max €890/year \\
\hline Denmark & No* & \\
\hline Finland & No* & \\
\hline France & Yes & Low: €200-650/year \\
\hline Germany & No & \\
\hline Greece & No* & \\
\hline Ireland & Yes, for MA & Medium: BA: free, MA: from €3800/year \\
\hline Italy & Yes & Medium: $€ 850-1000 /$ year \\
\hline Netherlands & Yes* & Medium€2000/year \\
\hline Norway & No & \\
\hline Poland & No* & \\
\hline Spain & Yes & Medium: BA: €680-1400/year, MA: 1350-1500/year \\
\hline Sweden & No* & \\
\hline Switzerland & Yes & Low: €550/year \\
\hline UK (England) & Yes* & High: €7500-12600/year \\
\hline
\end{tabular}

Sources: www.study.eu, www.mastersportal.eu, www.topuniversities.com

* There are fees for students from outside EU/EEA/Switzerland, and if a country has fees the fees for non-EU-students are set at a higher level.

Table 3: Typology of admissions systems

\begin{tabular}{|l|l|l|}
\hline \multicolumn{1}{|c|}{ Selection } & $\begin{array}{l}\text { (Nearly all) HEls can select } \\
\text { Sith additional criteria }\end{array}$ & $\begin{array}{l}\text { HEls cannot select with additional } \\
\text { criteria (in normal circumstances) }\end{array}$ \\
\hline $\begin{array}{l}\text { At least one pathway through } \\
\text { the school system does not } \\
\text { lead to a qualification } \\
\text { enabling HE-entry (to some } \\
\text { part of the system) }\end{array}$ & $\begin{array}{l}\text { Type 4: Double selection } \\
\text { Czech Republic, Iceland, } \\
\text { Montenegro, Norway, Romania, } \\
\text { Serbia, Slovakia, Spain, United } \\
\text { Kingdom }\end{array}$ & $\begin{array}{l}\text { Type 1: Selection by schools } \\
\text { Austria, Belgium, Denmark, } \\
\text { Germany, Hungary, Italy, } \\
\text { Luxembourg, Netherlands, Poland, } \\
\text { Slovenia }\end{array}$ \\
\hline $\begin{array}{l}\text { In general, all pathways may } \\
\text { lead to HE-entry (in some part } \\
\text { of the system) }\end{array}$ & $\begin{array}{l}\text { Type 2: Selection by HEls } \\
\text { Bulgaria, Croatia, Cyprus, } \\
\text { Estonia, Finland, Portugal, } \\
\text { Lithuania, Latvia }\end{array}$ & $\begin{array}{l}\text { Type 3: Least selection } \\
\text { Albania, France, Greece, Ireland, the } \\
\text { former Yugoslav Republic of } \\
\text { Macedonia, Malta, Sweden, Turkey }\end{array}$ \\
\hline
\end{tabular}

Source: Orr et al (2017:8). 


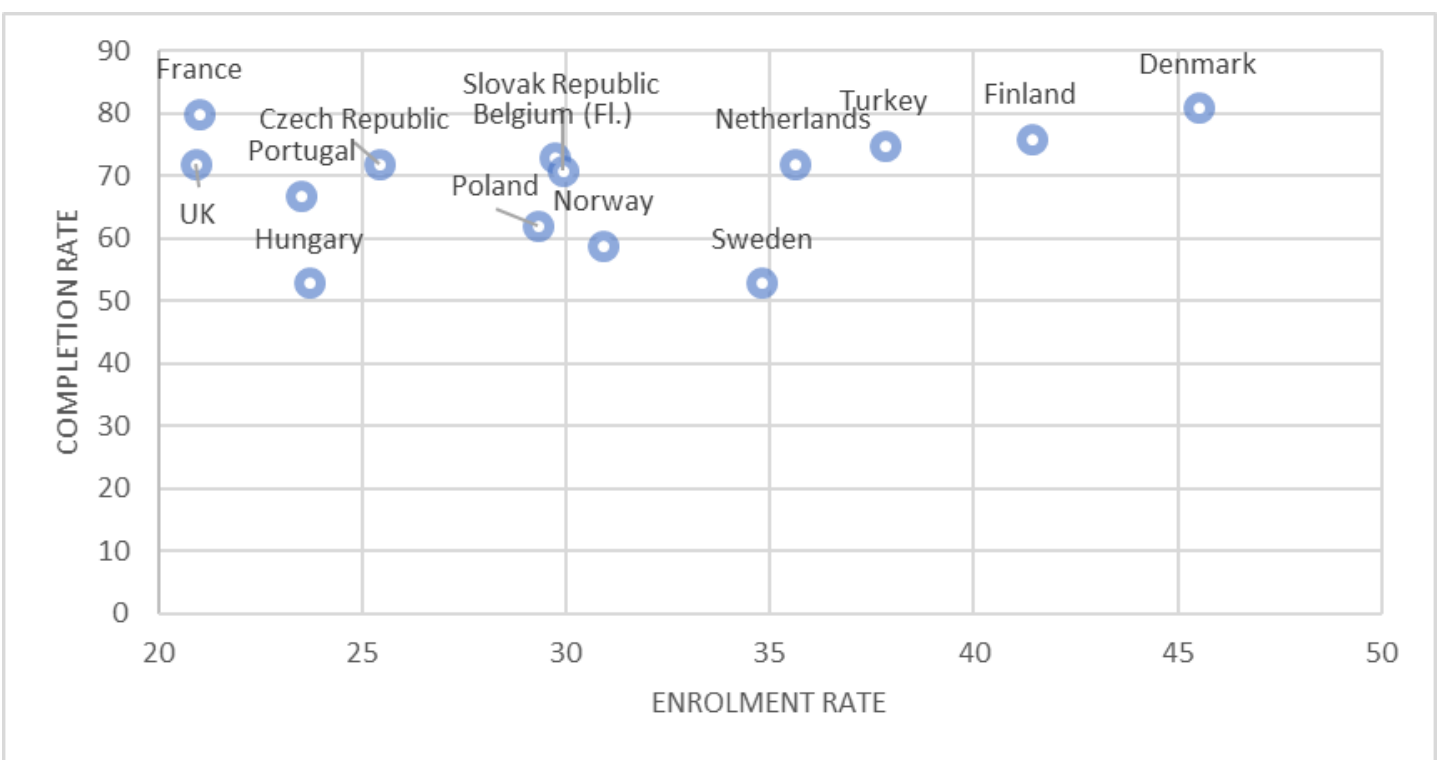

Figure 1: Correlation between enrolment rate and completion rate

Source: Completion rate: OECD Education at a Glance 2013, Indicator A4.1

Enrolment rate among 20-29-year olds, as a percentage of age group. Reference: OECD (2018), Enrolment rate (indicator). doi: 10.1787/1d7e7216-en (Accessed on 29 March 2018)

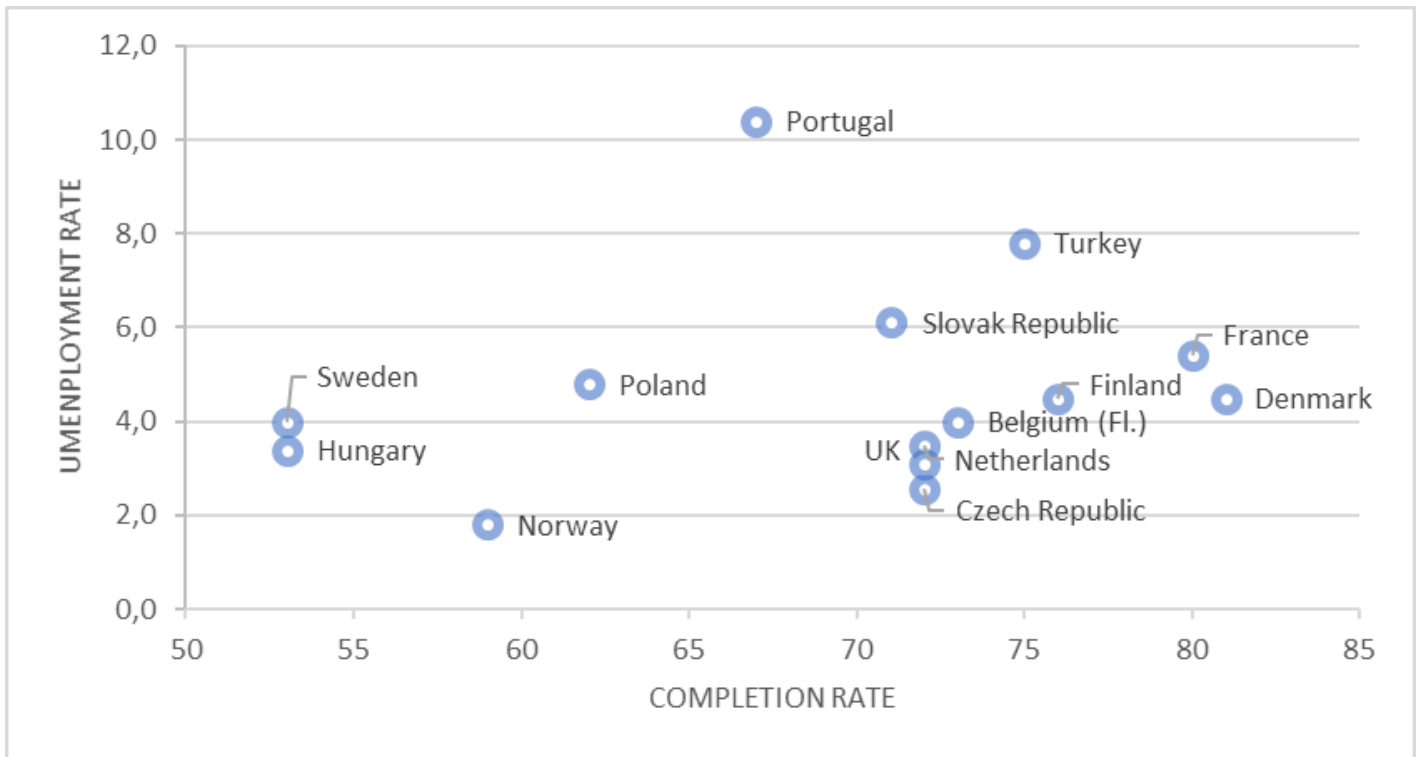

Figure 2: Correlation between completion rate and unemployment rate among those holding a tertiary degree (average rate over the years 2012-2014)

Source: Completion rate: OECD Education at a Glance 2013, Indicator A4.1

Unemployment rate calculated as the average rate in the three years following the data collection year for the completion rate (2011). Reference: OECD (2018), Unemployment rates by education level (indicator). doi: 10.1787/6183d527-en

(Accessed on 29 March 2018) 